\title{
W sprawie insygniów (atrybutów) miasta Lublina w XVII wieku
}

AвSTRAKT: W Lublinie w XVII-XVIII w. istniał zwyczaj sporządzania protokołu przekazania władzy burmistrza. W analizowanych zapisach $z$ lat ok. 1639-1655 objęciu władzy towarzyszyło przekazanie miejskich insygniów nowemu burmistrzowi. Jako insygnia miejskie w połowie XVIII w. wskazywane były buzdygan (berło), złoty pierścień burmistrzowski, pieczęć wielka miasta, pieczęcie miejskie żelazne, srebrny krucyfiks oraz krzyż do składania przysiąg, dzwonek radziecki, klucze wielkie miasta służące do przekazywania królowi oraz bęben miejski i konwie miejskie. W dotychczasowym rozumieniu archeologii prawnej przedmioty te należałoby zaliczyć do kategorii atrybutów władzy miejskiej. Na gruncie miejskim mamy zapewne do czynienia z recepcją prawa i rytuałów władzy państwowej, choć insygnia miejskie wydają się nie pełnić tak istotnej roli prawnej. Burmistrzowie Lublina oprócz insygniów przekazywali również szereg innych przedmiotów, związanych z bieżącym zarządzaniem miastem. Przedstawione uwagi na temat insygniów mają charakter wstępny i są pierwszą próbą przedstawienia podjętego tematu badawczego.

SŁOWA KLUCzowe: archeologia prawna, insygnia, insygnia miejskie, Lublin, miasto, zwyczaje miejskie, miejskie symbole.

Źródła historyczne dotyczące Lublina od I połowy XVII w. zawierają informacje o miejskich insygniach. Problematyka dawnych insygniów oraz innych przedmiotów, związanych z wykonywaniem władzy w mieście, jest przedmiotem badań nauk prawnych i historycznych, czyli archeologii prawnej oraz odpowia- 
dającej jej nauki o znakach władzy i prawa wśród nauk pomocniczych historii. Archeologia prawna nie wyróżnia insygniów miejskich jako kategorii symboli prawnych, pojęcie insygniów ograniczając do symboli związanych z władzą królewską i książęcą oraz dostojników kościelnych i rektorów uniwersytetów ${ }^{1}$. Pojęcie insygniów miejskich nie jest też używane na gruncie nauki o znakach władzy i prawa ${ }^{2}$. Na gruncie archeologii prawnej znany jest zespół przedmiotów i znaków reprezentujących miasto wraz z jego instytucjami. Oprócz tworzących osobną kategorię znaków prawnych (pieczęci, herbów, chorągwi, znaków granicznych, znaków produkcji rzemieślniczej, targowych i in.), wyróżnia się również odznaki urzędowe, takie jak: berła, buławy i buzdygany, klucze ławnicze oraz stroje niższych i wyższych urzędników miejskich ${ }^{3}$.

W założonej pod koniec lat 30. XVII w. osobnej księdze miejskiej Lublina wpisywane były czynności towarzyszące przekazaniu władzy nowemu burmistrzowi przez burmistrza ustępującego, w postaci sporządzenia wykazu przedmiotów nazywanych, przechowywanych w pomieszczeniu urzędu burmistrzowskiego (radzieckiego) oraz $\mathrm{w}$ pomieszczeniu miejskiego skarbca ${ }^{4}$. Przedmioty podlegające urzędowemu przekazaniu nie były wszakże określane mianem „odznak” czy „znaków” lecz wprost nazywane były insygniami miejskimi ${ }^{5}$.

Wymieniane w księdze miejskiej z XVII-XVIII w. insygnia miejskie Lublina nie były dotąd przedmiotem szerszego zainteresowania badawczego. Niektóre $\mathrm{z}$ nich, takie jak plakiety i odznaki z początku XX w. oraz symboliczne klucze do bram miejskich z 1757 r., przechowywane w zbiorach muzealnych, były przedmiotem publikacji w katalogu Insygnia miast polskich ${ }^{6}$. Na podstawie przywołanej księgi z protokołami przekazania insygniów miejskich z $1639 \mathrm{r}$. Zofia Froehlichowa do insygniów miejskich zaliczyła: „krucyfiks drewniany do juramentu, sygnet złoty, dzwonek, dwie pieczęcie: żelazna i srebrna, klucze do skarbca, klucze do baszty okrągłej, gdzie armata, klucze do wieży, gdzie prochy i zbroje, skrzynka radziecka z przywilejami, cztery kobierce"”. Uwagi poczynio-

1 W. Maisel, Archeologia prawna Polski, Warszawa 1982, s. 218-232.

J. Szymański, Nauki pomocnicze historii, Warszawa 2002.

3 W. Maisel, op. cit., s. 214-215, 234.

Archiwum Państwowe w Lublinie, Akta miasta Lublina 1465-1810, sygn. 240 (dalej: AmL).

Ibidem, k. 2v, 8, 11: ,insignia civitatis”, k. 12 ,13, 14, 15, 15V, 16, 17, 18, 20, 21, 23, 25, 27, nn.: „insignia”.

6 Insygnia miast polskich. Katalog wystawy, oprac. M. Mrugalska-Banaszak, M. Warkoczewska, Poznań 1992, s. 74-75, nr 13-16, 3, il. 73-75.

7 Z. Froehlichowa, Z dziejów organizacji władz miejskich $m$. Lublina do końca XVII wieku, „Pamiętnik Lubelski”, t. 1, 1927-1930, s. 88. 
ne na marginesie głównych ustaleń o insygniach miejskich Lublina nie trafiły do literatury z zakresu archeologii prawnej. Podejmowane obecnie opracowanie w postaci przyczynku powinno wprowadzić zagadnienie insygniów Lublina do literatury z zakresu archeologii prawnej oraz przyczynić się do sformułowania problematyki szerszych badań nad tym zagadnieniem, obejmującej także zagadnienia terminologii źródeł oraz współczesnej literatury naukowej, w tym rozumienia pojęcia „insygnia”. W tym miejscu zostaną one zestawione z zapisami dotyczącymi przekazywania insygniów z kolejnych lat, obejmującymi okres od pierwszego zapisu, tj. od około 1639 r. ${ }^{8}$ do 1655 r. Po tej dacie nastąpiła ponaddwudziestoletnia przerwa w zapisach o przekazaniu insygniów miejskich kolejnym burmistrzom, a początek czasowego ustania zapisów o insygniach przypada na okres zajęcia miasta przez Szwedów w 1655 r. ${ }^{9}$

Treść i kolejność wymienianych w protokołach przekazania władzy burmistrzowskiej przedmiotów nie miała ściśle ustalonego porządku i ulegała zmianom. Poszczególne obiekty wstępnie podzielić można na kilka grup: 1) przedmioty określane jako insygnia, 2) dokumenty regulujące stan prawny miasta, przechowywane w „skrzynce radzieckiej”, 3) dokumenty związane z bieżącym zarządzaniem miastem, 4) inne przedmioty związane w wykonywaniem władzy, przekazywane incydentalnie.

Zanim przejdziemy do przedstawienia najbardziej interesującego nas zagadnienia, jakim jest problematyka przedmiotów zaliczanych do miejskich insygniów, zatrzymajmy się nad zawartością wymienionej wyżej drugiej i trzeciej grupy przedmiotów, wymagających odnotowania przy przekazaniu władzy burmistrza.

Drugą, obok insygniów miejskich, najliczniejszą grupą przedmiotów, podlegających przekazaniu, były dokumenty regulujące stan prawny miasta, czyli jego przywileje, z przywilejem lokacyjnym Lublina z 1317 r. na czele. Wykazy przekazywanych przedmiotów wymieniają również odpisy przywilejów miejskich, zapewne mowa o kopiariuszu miejskim ${ }^{10}$, zwanym „księgą pergaminową z przywilejami” lub określanym jako „księgi pergaminowe privilegiorum, pisa-

8 Pierwszy wpis o przekazaniu insygniów na rok 1639 datuje Z. Froehlichowa (op. cit., s. 88). Data taka możliwa jest również z punktu widzenia ustaleń dotyczących wykazu burmistrzów J. Riabinina (Rada miejska lubelska w XVII wieku, Lublin 1931, s. 37).

9 AmL, sygn. 240, k. 30, 40v.

${ }^{10} \mathrm{O}$ kopiariuszu dokumentów miejskich Lublina założonym w I połowie xvi w. i znajdującym się w nim spisie przywilejów z 1699 r. zob. P. Dymmel, Spis dokumentów miasta Lublina $z 1699$ roku, [w:] Historia memoria scriptum. Księga jubileuszowa z okazji osiemdziesięciolecia urodzin profesora Edwarda Potkowskiego, red. J. Krochmal, Warszawa 2015, s. 98-114. 
ne"11. Przywileje miasta przechowywane w „skrzynce radzieckiej” wyjmowane były niekiedy w celu przedłożenia ich kolejnym władcom do potwierdzenia. $\mathrm{Na}$ przykład w 1649 r. do skrzyni został na powrót złożony „privilegio numero dwadzieścia od pana [burmistrza] Aleksandra Konopnicy, który wziął dla confirmacyji Jego Mości Króla do Krakowa”. Z kolei w 1655 r. do Warszawy przewieziony został, zapewne w podobnym celu, przywilej lokacyjny Lublina („privilegium fundationis Civitatis [anni] 1317 w Warszawie u pana Cieszyckiego") ${ }^{12}$.

Poza „skrzynią radziecką” przechowywane były przywileje i dokumenty związane $\mathrm{z}$ bieżącym zarządem miasta, obejmujące aktualne przywileje miasta (np. zwolnienie od podwód), konstytucje sejmowe, zarządzenia władz państwowych, wyroki sądów oraz dokumenty związane z toczącymi się sprawami z udziałem miasta przed różnymi sądami. Ta część dokumentów miasta, nazywana „munimentami”, składana była w „fascykułach” w kilku miejscach miejskiego skarbca, w większości w „szufladzie drewnianej”, w „koszu plecionym”, w „torbie skórzanej” oraz w „skrzyniach”"13.

Wśród insygniów miejskich, wyszczególnianych do 1655 r., na pierwszym miejscu często wymieniany był sygnet burmistrzowski, określany także jako "sygnet złoty"14. Przyjąć należy, że złoty sygnet burmistrza, służący do noszenia jako pierścień na palcu ręki, był jednocześnie niewielkich rozmiarów pieczęcią urzędową lubelskich burmistrzów. Z zachowanych odcisków pieczęci na dokumentach wystawianych przez burmistrza i radę miasta wiadomo, że Lublin posiadał przynajmniej dwa sygnety ${ }^{15}$, jeden $\mathrm{z}$ nich najpewniej wymieniany jest $\mathrm{w}$ przywoływanych wykazach insygniów. Po sygnecie burmistrzowskim ${ }^{16}$, często wraz $\mathrm{z}$ nim $^{17}$, zapewne jako zestaw pieczęci pozostających $\mathrm{w}$ dyspozycji burmistrza, wymieniane były „dwie pieczęci żelazne”. Wśród przedmiotów zaliczanych do insygniów stale występowała jeszcze jedna pieczęć, przechowywana jednak w zamknięciu w „skrzyni radzieckiej”, w XVII w. zapewne nieużywana już do pieczętowania dokumentów, lecz pieczęć dawniejsza. Być może była to najdawniejsza gotycka pieczęć miasta lub inna, równie dawna pieczęć

${ }_{11}$ AmL, sygn. 240, k. 11, 12V, 15, 15V i nn.

12 Ibidem, k. 25, 30.

${ }_{13}$ Ibidem, k. 8, 13, 14V, 16v, 21, 25 .

14 Ibidem, k. 1 i nn.

${ }^{15}$ M. Trojanowska, Wizerunki herbu miasta Lublina w źródłach archiwalnych $z$ XV-XVIII wieku, „Studia Archiwalne”, t. 4, 2017, s. 14 (il. 3, 4).

16 AmL, sygn. 240, k. 1: „dwoje pieczęci żelazne”.

17 Ibidem, k. 8: „signet złoty i dwie żelazne pieczęci”. 
rady miejskiej ${ }^{18}$. Przechowywanie tej pieczęci przez miasto razem $\mathrm{z}$ insygniami miejskimi wiązało się także $\mathrm{z}$ jej wartością materialną. Była wykonana ze srebra, nazywana z reguły „pieczęcią srebrną” („,skrzynka radziecka z przywilejami i z pieczęcią srebrną" ${ }^{19}$ ), lecz wydaje się, że jej rzeczywiste znaczenie dla miasta lepiej oddawało nazwanie jej „pieczęcią wielką miejską” („skrzynka z przywilejami i z pieczęcią wielką miejską" - wzmianka z $1644 \mathrm{r}^{20}{ }^{20}$.

Następne w kolejności po pieczęciach miejskich, złotym sygnecie burmistrzowskim, dwóch zwykłych pieczęciach urzędowych oraz wykonanej ze srebra wielkiej pieczęci miasta przedmioty przeznaczone były do zastosowania w związku z obradami rady miejskiej. Mowa o dwóch krucyfiksach - drewnianym i srebrnym, dwóch dzwonkach - srebrnym i mosiężnym, bębnie miejskim oraz buzdyganie. Pierwszorzędne znaczenie krucyfiksu wiąże się z sądem miejskim oraz ze składanymi tam przysięgami. Posługiwanie się przedmiotami w czasie składania przysiąg - relikwiarzami i krucyfiksami trafiło do zwyczajów i prawa miejskiego być może pod wpływem zwyczajów sądownictwa kościelnego $^{21}$. Krucyfiksy służące także jako atrybuty towarzyszące składaniu przysięgi znane są i z innych instytucji sądowych, w tym również z obrad Trybunału Koronnego w Lublinie, posiadającego własny zestaw symboli i insygniów, w tym laskę marszałka, krzyż, dzwonek oraz skrzynkę srebrną ${ }^{22}$. Z pamiętnikarstwa znana jest relacja o tym, że „w Trybunale Lubelskim na pulpicie, przy którym wygłaszali swe mowy adwokaci, stał krzyż zwrócony w stronę kolegium sądzącego. Miał on zawierać ostrzegawczy w swej wymowie napis: Iudicia vestra iudicabo, tj. sądy wasze będę sądził"23. Dawny krzyż z Trybunału Koronnego, według tradycji ufundowany przez Jana Zamoyskiego, dziś znajduje się w ołtarzu kaplicy św. Stanisława Kostki w lubelskiej archikatedrze ${ }^{24}$. W zbiorach muzealnych zachowały się niektóre krzyże będące dawniej na wyposażeniu władz miejskich, niekiedy nazywane krzyżami magistrackimi, np. w: Poznaniu z początku XVII w., Rzeszowie (XIX w.), Tarnowie (XVII w.), Toruniu (XIV w.), Warszawie

\footnotetext{
18 O najstarszej pieczęci Lublina zob. M. Gumowski, Najstarsze pieczęcie miast polskich XIII i XIV wieku, Toruń 1960, s. 135, nr 247, tabl. XIX. Ostatnio: M. Trojanowska, op. cit., s. 13.

19 AmL, sygn. 240, k. 1.

20 Ibidem, k. $15 \mathrm{v}$.

21 W. Maisel, op. cit., s. 167.

22 K. Gombin, Trybunał Koronny. Ceremoniał i sztuka, Lublin 2013, s. 94.

23 W. Maisel, op. cit., s. 167; K. Gombin, op. cit., s. 95-96.

24 K. Gombin, op. cit., s. 94, 219.
} 
$\left(\right.$ XVIII w. ${ }^{25}$. Pierwszy krucyfiks wymieniany wśród insygniów miejskich Lublina to krucyfiks drewniany, określany jako: „krucyfiks drewniany do składania przysiąg” („Crucifix drewniany ad iuramenta”), „krucyfiks drewniany z donatem”, „krzyż do iuramentum”, a także jako „krucyfiks stary drewniany” ${ }^{26}$. „Donatem" nazywano księgę wymienianą w wykazie insygniów często w połączeniu z krucyfiksem, zawierającą roty przysiąg oraz uchwał rady miejskiej („Donat w którym continentur lauda civitatis i rothorum iuramentorum officialium civitatis” - zapis z 1649 r. $^{27}$ ). Nazwa „krucyfiks drewniany stary” używana była także, by odróżnić go od sprawionego przez miasto nowego srebrnego krzyża, który najczęściej nazywany był „krucyfiks srebrny” („krzyż srebrny”) lub „krucyfiks srebrny od klejnota"28. Z tej ostatniej nazwy wynika, że srebrny krzyż być może był częścią jakiejś większej całości nazywanej „klejnotem”. Nie wiemy, jak wyglądał ów klejnot. Przez analogie do dawnych krucyfiksów magistrackich zwłaszcza pochodzącego z początku XVII w. z sali sądowej poznańskiego ratusza pełnoplastycznej rzeźby krzyża sądowego, złożonego z figury Chrystusa, wizerunków świętych postaci, wizerunku Jerozolimy oraz napisów ${ }^{29}$ - można jedynie przypuszczać, że mógł zawierać przedstawienie pasyjne.

Wśród lubelskich insygniów znajdowały się dwa dzwonki. Protokół przekazania insygniów z 1655 r. wymienia: „dzwonki dwa, jeden srebrny i drugi spiżowy"30. We wcześniejszych wpisach wymieniany jest tylko jeden z nich, na ogól nazywany „dzwonek srebrny”, ale stosowano także nazwę rzucającą światło na jego funkcję: „dzwonek radziecki” ${ }^{31}$. Można w nim zatem rozpoznać przedmiot zaliczany przez archeologię prawną do instrumentów sygnalizacji dźwiękowej ${ }^{32}$. Tego rodzaju przedmiotami były dzwony zawieszane na wieżach ratuszowych, służące do zwoływania mieszczan (posiadał go także ratusz lubelski). Natomiast na posiedzeniach rady oraz podczas zebrań do utrzymania porządku posługiwano się małymi dzwonkami ręcznymi. Zachowane ręczne dzwonki ratuszowe,

\footnotetext{
${ }^{25}$ Insygnia miast polskich, s. 95-96.

${ }^{26}$ AmL, sygn. 240, k. 1V, 2V, 8, 11, 12, 17, 23.

27 Ibidem, k. 23.

${ }^{28}$ Ibidem, k. 1V, 2v, 14V, 15, 17, 18.

${ }^{29}$ Insygnia miast polskich, s. 95, il. 103.

${ }^{30}$ AmL, sygn. 240, k. 30.

${ }^{31}$ Ibidem, k. 20.

32 W. Maisel, op. cit., s. 170.
} 
ozdobione wizerunkami, symbolami i napisami, znane są m.in. z Bydgoszczy i Śremu ${ }^{33}$.

Innym instrumentem sygnalizacji dźwiękowej, będącym $w$ posiadaniu miasta, był „bęben miejski” "34. Jeśli znajdował się w wykazie insygniów, a nie zdarzało się to często, wpisywany był na końcu listy. Wykaz insygniów z $1641 \mathrm{r}$. wymienia również dobosza miejskiego, któremu burmistrz przekazał jeden ze służbowych ubiorów miejskich, czerwoną katankę ${ }^{35}$. Z zapisów z innych miast wiadomo, że bębny miejskie służyły do zwoływania mieszczan w celu przekazania im komunikatów, mogły też sygnalizować porę zamykania bram miejskich ${ }^{36}$.

Niewiele wiadomo o buzdyganie, wymienionym w wykazie insygniów tylko raz. W źródle z ok. 1640 r. czytamy: „rzeczy od pana Alexandra Konopnicy odebrane, tak skrzynki, munimenta i insze drobiazgi pan pisarz radziecki do skarbnicy pozanosił, przy których rzeczach i buzdygan" ${ }^{37}$. Z zapiski tej, a także z milczenia o buzdyganie $\mathrm{w}$ spisach insygniów miejskich przez następnych kilkanaście lat do 1655 r., może wynikać, że insygnium tego używano nieczęsto i nie wyjmowano ze skarbca. Z jednej strony miejsce przechowywania buzdyganu świadczy o jego istotnej roli wśród insygniów, $\mathrm{z}$ drugiej strony milczenie o nim w wykazach insygniów w kolejnych latach sugeruje, że mógł być zarezerwowany tylko na ważniejsze uroczystości miejskie. Dla odróżnienia od bereł królewskich lub rektorskich nazywane są również berełkami. Geneza znaczenia buzdyganu łączy się z berłami miejskimi burmistrzów i cechmistrzów, znanymi od średniowiecza. Najbardziej znane berło miejskie pochodzi z Krakowa. Posiada głowicę z koroną królewską oraz widnieje na nim napis napominający „Iudicate iuste filii hominum” („Sądźcie sprawiedliwie synowie człowieczy") ${ }^{38}$. W czasach nowożytnych miasta dysponowały buławami i buzdyganami, których nazwy nawiązywały do bardziej powszechnych insygniów wojskowych. Buławy i buzdygany były popularnymi i w niemałej liczbie zachowanymi insygniami cechmistrzowskimi np. w Krakowie ${ }^{39}$.

Kolejną grupę przedmiotów zaliczanych w dawnym Lublinie do insygniów stanowiły klucze miejskie. Przejmowanie kluczy przez burmistrza rozpoczynającego urzędowanie od swojego poprzednika było znakiem rzeczywistego ob-

\footnotetext{
33 Insygnia miast polskich, s. 96-97.

34 AmL, sygn. 240, k. 1v, 8.

35 Ibidem, k. 8.

36 W. Maisel, op. cit., s. 309.

37 AmL, sygn. 240, k. 8.

38 W. Maisel, op. cit., s. 234.

39 Ibidem.
} 
jęcia urzędu. Poczucie faktycznego sprawowania władzy dawało przejęcie kluczy do drzwi niektórych instytucji miejskich. Wśród kluczy przekazywanych przez kończącego urzędowanie burmistrza znajdowały się: klucze do skarbca miejskiego, klucze do archiwum miejskiego, klucze do więzienia („klucze od więzienia i ab archivo civitatis" ${ }^{\prime 40}$ ), klucze do baszty okrągłej, w której przechowywane były miejskie armaty, oraz do drugiej wieży, w której składowane były proch oraz zbroje („klucze od okrągłej baszty, gdzie armata”, „klucze od wieży, gdzie prochy i zbroje") ${ }^{41}$. Niekiedy podczas przekazywania urzędu burmistrza klucze nazywano ogólnym określeniem „klucze wszystkie” („klucze wszystkie miejskie") ${ }^{42}$. Wspólne wymienienie przekazywanych kluczy powodowało rzadko spotykane, oddzielne, podanie wiadomości, że wśród nich były także klucze „od izby radzieckiej”, „od skrzynki radzieckiej” („do skrzynki do przywilejów”) czy do nowo wykonanej furty miejskiej „furty nowej za łaźnią”"33.

Jednak najważniejsze znaczenie miały klucze zwane niekiedy „od miasta”, lub określane dokładniej jako „klucze dwa miejskie wielkie” lub „klucze dwa wielkie i z trzecim małym, które się Królowi Jego Mości zwykło oddawać" ${ }^{44}$. Były to więc klucze do miasta, inaczej zwane kluczami od bram miejskich, które przedstawiciele miasta wręczali królowi jako swemu panu zwierzchniemu podczas jego wjazdu do miasta. Inny chyba już zestaw takich kluczy miejskich miasta Lublina, z datą „1757”, zachował się do czasów współczesnych i przechowywany jest w Muzeum Miasta Lublina ${ }^{45}$.

$\mathrm{Z}$ pozostałych przedmiotów metalowych, $\mathrm{w}$ Lublinie zaliczanych do insygniów miejskich, a według archeologii prawnej należących do sprzętów używanych w administracji, wymienić należy konwie cynowe, które znajdowały się na wyposażeniu urzędu burmistrzowskiego („konwi, które żurawiami zowią, cynowe, sześć" $\left.{ }^{\prime 46}\right)$. Przedmioty te miały najpewniej zastosowanie praktyczne, związane $\mathrm{z}$ przyjęciami i ucztami wydawanymi $\mathrm{w}$ ratuszu ${ }^{47}$. W protokołach przekazania urzędu burmistrzowskiego wymieniane są również kobierce („kobierców

\footnotetext{
${ }^{40}$ AmL, sygn. 240, k. 30.

${ }^{41}$ Ibidem, k. 1, 2v.

${ }^{42}$ Ibidem, k. 8, 11, 12, 13, 14V, 15.

${ }^{43}$ Ibidem, k. 14V, 15, 20, 22.

${ }^{44}$ Ibidem, k. 1, 2V, 17, 18, 30.

${ }^{45}$ Insygnia miast polskich, s. 74, il. 73.

46 AmL, sygn. 240, k. 1, 2V, 17, 18.

${ }^{47}$ M. Warkoczewska, Insygnia, atrybuty $i$ symbole władzy $w$ dawnych miastach polskich, [w:] Insygnia miast polskich, s. 17.
} 
cztery”, „kobierce dwa tureckie” ${ }^{48}$. Można przypuszczać, że zestawienie konwi wraz z insygniami wiązało się z ich walorami dekoracyjnymi; być może tak, jak naczynia znane $\mathrm{z}$ innych miast, np. konwie miejskie Warszawy ${ }^{49}$, były bogato zdobione z wykorzystaniem miejskich symboli.

Wyliczeniom miejskich insygniów towarzyszą również zapisy o przedmiotach czasowo przechowywanych $\mathrm{w}$ ratuszu miejskim. W wykazie insygniów z 1641 r. spotykamy informację o przechowywanych w urzędzie burmistrzowskim ubiorach należących do niższych urzędników miejskich. Należały do nich dwa rodzaje ubiorów wierzchnich, delie oraz katanki ${ }^{50}$, pozostające na wyposażeniu sług miejskich. Wzmiankowana jest: „delia barwiana sługi Stanisława, w której się odprawuje”, innym razem „delii dwoje czerwonych" ${ }^{1}$. Wierzchnie ubiory używane były w Lublinie przez służbę miejską, podległą urzędowi radzieckiemu z burmistrzem, radzie miejskiej, a także przez niższych urzędników, podległych urzędowi wójtowskiemu. Zgodnie $\mathrm{z}$ dokumentem, zawierającym ugodę magistratu z pospólstwem Lublina, zatwierdzoną przez króla Jana Kazimierza 26 VIII 1651 r., woźni („bedelli”) urzędu wójtowskiego, będący urzędnikami zobowiązanymi do złożenia przysięgi, każdego roku mieli na koszt miasta otrzymywać „suknie zwierzchnie” ${ }^{2}$. Możemy doszukać się tu analogii z deliami przechowywanymi w $1641 \mathrm{r}$. w urzędzie burmistrzowskim. Należy również zwrócić uwagę, że wzmianka o „delii barwianej” z 1641 r. podkreśla także jej oficjalną rolę, wskazując na "odprawowane”, wykonywane ${ }^{53} \mathrm{w}$ tym ubiorze nieokreślone bliżej czynności urzędowe przez sługę miejskiego Stanisława.

Obecność w Lublinie ubioru służby miejskiej było niewątpliwie częścią szerszego zjawiska, znanego $\mathrm{z}$ innych miast polskich, wyposażania niższych urzędników w stroje określane mianem „barwy”, czyli ubioru jednakowego koloru. Zwyczaj wyposażania przez miasto niższych urzędników w ujednolicony ubiór spotykany jest w Polsce już XIV w..$^{54}$ Zjawisko „barwy” jako ubioru sług miejskich szerzej znane jest od wieku XVI. Rada miejska Krakowa 26 III 1528 r.

\footnotetext{
${ }^{48}$ AmL, sygn. 240, k. 1, 11, nn.

49 Insygnia miast polskich, s. 86-87, il. 91-92.

${ }_{50}$ Por. S. B. Linde, Słownik języka polskiego, t. 1, cz. 1-2, Warszawa 1807-1808, s. 417, 977-978.

${ }^{51}$ AmL, sygn. 240, k. 8.

${ }^{52}$ Materiały do monografii Lublina. Wilkierze XV-XVII wieku, wyd. L. Białkowski, Lublin 1928, s. 34 (dalej: Wilkierze XV-XVII wieku).

${ }^{53}$ Słownik polszczyzny XVI wieku, t. 20, red. M. R. Mayenowa, F. Pepłowski, Warszawa 1991, s. 405 .

${ }^{54}$ W. Maisel, Insygnia, odznaki godności i stroje dawnych polskich urzędników samorządowych, [w:] Polskie tradycje samorządowe a heraldyka. Materiały sesji naukowej zorganizowanej
} 
zarządziła ujednolicony, jednobarwny ubiór („unicoloris”) służby miejskiej, zwanej policją („pollicia civitatis”) ${ }^{55}$. O wydatkach na zakup „barwy” dla miejskiej czeladzi informują przekazy z 1592 r. z Poznania. Z kolei z 1777 r., także z Poznania, pochodzi wzmianka ukazująca w szerszym świetle zakres stosowania ujednoliconego ubioru miejskiego. $\mathrm{Z}$ poznańskiego raportu na temat wydatków kasy miejskiej, skierowanego do Rady Nieustającej, wynika, że miasto wydatkowało kwoty na „barwę”, która przysługiwała dowódcy straży miejskiej zwanemu „hutmanem”, trębaczowi miejskiemu oraz sześciu pachołkom pilnującym ratusza i aresztantów ${ }^{56}$. Do ubioru pachołków poznańskich z II poł. XVIII w. nawiązuje również zapis z inwentarza z 1780 r., wymieniający „sześć katanek zielonych", a więc krótkich kurtek, przechowywanych w Poznaniu pod kontrolą hutmana. Z tego samego roku pochodzi zalecenie poznańskiej Komisji Dobrego Porządku względem wyglądu katanek sług miejskich. Miały być szyte z jednego postawu sukna, tego samego koloru, miały też mieć pasowe wyłogi, a na lewej piersi katanek miały zostać umieszczone wycięte z czerwonego sukna skrzyżowane klucze, a więc symbol tzw. małego herbu miasta Poznania ${ }^{57}$.

Znajdujemy niewiele wiadomości źródłowych podanych przez literaturę przedmiotu na temat ubiorów wyższych urzędników miejskich. Tymczasem odnotowane, pojedyncze przekazy wydają się wskazywać na fakt posiadania ubiorów także przez wyższych urzędników miejskich. O istnieniu własnego ubioru ławników miejskich świadczy publiczne występowanie ławników miejskich Gdańska w brunatnych sukiennych płaszczach, zdobionych złotym galonem. Według przekazu z 1766 r. płaszcze te miały być już szyte z czarnego jedwabiu lub $\mathrm{z}$ aksamitu ${ }^{58}$. Na uwagę zasługuje również uchwała rady miejskiej Lublina z 1539 r., zgodnie z którą wymagano, aby rajcy podczas wystąpień publicznych zdejmowali nakrycie nazwane „bireto vel mitra” ${ }^{9}$. W sprawie nakrycia głowy wymienionego w uchwale rady miejskiej Lubina W. Maisel wyraził pogląd, że może chodzić o nakrycie głowy „urzędowe”60.

\footnotetext{
$w$ dniach 4 i 5 czerwca 1991 r. w Lublinie, red. P. Dymmel, Lublin 1992, s. 69; tenże, Stroje, insygnia i odznaki godności polskich urzędników miejskich, [w:] Insygnia miast polskich, s. 24.

${ }_{55}$ Prawa, przywileje i statuta miasta Krakowa, t. 1, cz. 1, wyd. F. Piekosiński, Kraków 1885, s. $55, \mathrm{nr} 38$.

${ }_{56}$ W. Maisel, Stroje, insygnia i odznaki, s. 24.

${ }^{57}$ Ibidem.

${ }^{58}$ Ibidem, s. 25.

59 Wilkierze XV-XVII wieku, s. 9.

${ }^{60}$ W. Maisel, Stroje, insygnia i odznaki, s. 24.
} 
Podsumowując poczynione, wstępne uwagi na temat wymienianych w źródłach historycznych insygniów miejskich Lublina, należy skłonić się ku tezie, że w rozumieniu archeologii prawnej mamy do czynienia raczej z atrybutami miejskimi. Ponadto, wydaje się, że aby w świetle archeologii prawnej jako insygnia uznać: buzdygan, pierścień burmistrzowski, pieczęć wielką, pieczęcie miejskie żelazne, srebrny krucyfiks i krzyż do składania przysiąg, dzwonek radziecki, wielkie klucze miejskie, bęben miejski, konwie miejskie i inne przedmioty brakuje odpowiednich przesłanek historyczno-prawnych. Przesłanką kwalifikującą przedmioty związane z wykonywaniem władzy do insygniów jest nieodzowność ich przekazania w zgodzie z prawem i zwyczajem, czyli według określonego obrzędu oraz współkonstytuowanie w ten sposób legalnej władzy. Tymczasem insygniom miejskim nie przyznaje się mocy udziału w kreacji władzy. Jak zaznaczono w przytaczanej lubelskiej księdze miejskiej z XVII-XVIII w., na początku jej zapisów o przekazywaniu insygniów i innych przedmiotów, czyniono to m.in. z uwagi na zamiar zapobieżenia ich zgubieniu ${ }^{61}$. Nie wiadomo, czy przekazaniu władzy burmistrza towarzyszył ustalony rytuał. Na przeszkodzie wykształcenia się ceremonii przekazania władzy burmistrza stać mogły względy praktyczne i rutyna związana z częstymi, cokwartalnymi zmianami na urzędzie burmistrza. Pojęcie „insygnia miejskie” jest nie tylko terminem historycznym. Występuje ono także we współczesnej literaturze naukowej oraz we współczesnym ustawodawstwie. Przykładem dobrze znanego dawnego symbolu władzy miejskiej w Polsce, określanego przez literaturę przedmiotu jako „insygnium”, jest krakowskie berełko z XVI w. ${ }^{62}$ Do przypomnienia insygniów miejskich Lublina, samego pojęcia i jego treści, zachęca także współczesne ustawodawstwo polskie, które w odniesieniu do symboli władz samorządowych określa możliwość posiadania przez jednostki samorządu terytorialnego własnych insygniów ${ }^{63}$. Niniejsze opracowanie jest pierwszym opracowaniem poświęconym dawnym insygniom Lublina, powstałym w związku z zamierzeniem podjęcia szerszych studiów nad tym zagadnieniem.

\footnotetext{
${ }^{61}$ AmL, sygn. 240, k. 1.

${ }^{62}$ Kraków - europejskie miasto prawa magdeburskiego (1257-1791). Katalog wystawy, Kraków 2007, s. 202-203.

${ }^{63}$ Ustawa z dnia 21 grudnia 1978 r. o odznakach i mundurach - art. 3 ust. 1 (Dz. U. z 1978 r. nr 31, poz. 130 z późn. zm.).
} 


\section{Summary}

\section{On the Insignia (Symbols) of the City of Lublin in the $17^{\text {th }}$ Century}

In Lublin, in the $17^{\text {th }}$ and $18^{\text {th }}$ century there was a custom of making a record of the handing over of the mayor's office. According to the analyzed records of ca. 1639-1655 the takeover of office was accompanied by the handing over of the city insignia to the new mayor. As recorded, in the mid- $18^{\text {th }}$ century the city insignia comprised: the mace (scepter), the mayor's gold ring, the grand seal of the city, the city's iron seals, a silver crucifix and a cross for swearing oaths, the city council bell, the great keys of the city to be handed over to the king as well as the city drum and city cans. These objects, as currently defined by legal archeology, should be classified as symbols of city authority. In the municipal context, we are probably dealing with the reception of law and the rituals of state authority although the city insignia do not seem to fulfill such a significant legal function. In addition to the insignia, the mayors of Lublin also handed over a number of other objects connected with the systematic management of the city. The presented remarks on the insignia are preliminary and are the first attempt to present the chosen research subject.

KEYWORDS: legal archeology, insignia, city insignia, Lublin, city, city symbols, urban customs.

\section{Bibliografia}

Dymmel P., Spis dokumentów miasta Lublina z 1699 roku, [w:] Historia memoria scriptum. Księga jubileuszowa z okazji osiemdziesięciolecia urodzin profesora Edwarda Potkowskiego, red. J. Krochmal, Warszawa 2015, s. 98-114.

Froehlichowa Z., Z dziejów organizacji władz miejskich $m$. Lublina do końca XVII wieku, „Pamiętnik Lubelski”, t. 1, 1927-1930, s. 69-115.

Gombin K., Trybunał Koronny. Ceremoniat i sztuka, Lublin 2013.

Gumowski M., Najstarsze pieczęcie miast polskich XIII i XIV wieku, Toruń 1960. Insygnia miast polskich. Katalog wystawy, oprac. M. Mrugalska-Banaszak, M. Warkoczewska, Poznań 1992.

Kraków - europejskie miasto prawa magdeburskiego (1257-1791). Katalog wystawy, Kraków 2007. 
Linde S. B., Słownik języka polskiego, t. 1, cz. 1-2, Warszawa 1807-1808.

Maisel W., Archeologia prawna Polski, Warszawa 1982.

Maisel W., Insygnia, odznaki godności i stroje dawnych polskich urzędników samorzadowych, [w:] Polskie tradycje samorzadowe a heraldyka. Materialy sesji naukowej zorganizowanej w dniach 4 i 5 czerwca 1991 r. w Lublinie, red. P. Dymmel, Lublin 1992.

Materiały do monografii Lublina. Wilkierze XV-XVII wieku, wyd. L. Białkowski, Lublin 1928.

Prawa, przywileje i statuta miasta Krakowa, t. 1, cz. 1, wyd. F. Piekosiński, Kraków 1885.

Riabinin J., Rada miejska lubelska w XVII wieku, Lublin 1931.

Słownik polszczyzny XVI wieku, t. 20, red. M. R. Mayenowa, F. Pepłowski, Warszawa 1991.

Szymański J., Nauki pomocnicze historii, Warszawa 2002.

Trojanowska M., Wizerunki herbu miasta Lublina w źródłach archiwalnych $z$ XV-XVIII wieku, „Studia Archiwalne”, t. 4, 2017, s. 11-29.

Warkoczewska M., Insygnia, atrybuty i symbole władzy $w$ dawnych miastach polskich, [w:] Insygnia miast polskich, oprac. M. Mrugalska-Banaszak, M. Warkoczewska, Poznań 1992. 